\title{
Activity of Iron Oxide in Magnesiowüstite in Equilibrium with Solid Metallic Iron
}

\author{
Masakatsu Hasegawa, Tatsuro Tsukamoto* and Masanori Iwase \\ Department of Energy Science and Technology, Kyoto University, Kyoto 606-8501, Japan
}

By employing an electrochemical technique incorporating magnesia-stabilized zirconia electrolyte, the activities of iron oxide, Fe $\mathrm{O}$, were measured in magnesiowüstite, $\mathrm{Fe}_{x} \mathrm{O}-\mathrm{MgO}$ solid solution, in equilibrium with solid metallic iron at temperatures between 1373 and $1573 \mathrm{~K}$. The sub-regular solution model was applied to the $\mathrm{Fe}_{x} \mathrm{O}$ activities, and the calculated $\mathrm{Fe}_{x} \mathrm{O}$ activities were in good agreement with the experimental values in this study and the literatures at temperatures between 1073 and $1573 \mathrm{~K}$ with an accuracy of \pm 0.02 .

(Received December 1, 2005; Accepted January 23, 2006; Published March 15, 2006)

Keywords: magnesiowüstite, $\mathrm{FeO}-\mathrm{MgO}$ solid solution, activity, sub-regular solution model, magnesia-stabilized zirconia

\section{Introduction}

Magnesium oxide, $\mathrm{MgO}$, is one of the important components of blast furnace slag. For better understanding the activity of iron oxide, $\mathrm{Fe}_{x} \mathrm{O}$, in blast furnace slag, it is essential to estimate the interaction between $\mathrm{Fe}_{x} \mathrm{O}$ and $\mathrm{MgO}$. Magnesiowüstite, $\mathrm{Fe}_{x} \mathrm{O}-\mathrm{MgO}$ solid solution, is known to be continuous between the end members at temperatures below the melting point of $\mathrm{Fe}_{x} \mathrm{O}$, i.e., $1644 \mathrm{~K}$, shown in Fig. 1. ${ }^{1-3)} \mathrm{A}$ number of studies have been done on the system of $\mathrm{Fe}_{x} \mathrm{O}-$ $\mathrm{MgO}$ in equilibrium with solid metallic iron. The $\mathrm{Fe}_{x} \mathrm{O}$ activities reported for $\mathrm{Fe}_{x} \mathrm{O}-\mathrm{MgO}$ solid solutions at 1573, $1473,1373,1273,1173,1123$ and $1073 \mathrm{~K}$ are summarized in Fig. 2.

Schmahl et al. $^{4)}$ measured the $\mathrm{Fe}_{x} \mathrm{O}$ activities in $\mathrm{Fe}_{x} \mathrm{O}-$ $\mathrm{MgO}$ solid solutions equilibrated with pure iron in the gas mixture of $\mathrm{CO}+\mathrm{CO}_{2}$ at 1073,1173 and $1273 \mathrm{~K}$. Their data are expressed by open squares in Fig. 2.

Hahn and Muan ${ }^{5)}$ determined the chemical potentials of $\mathrm{Fe}_{x} \mathrm{O}$ at 1373 and $1573 \mathrm{~K}$ by using gas equilibrium technique involving $\mathrm{CO}_{2}+\mathrm{H}_{2}$. Open circles in Fig. 2 express their values.

Half-filled triangles in Fig. 2 show the $\mathrm{Fe}_{x} \mathrm{O}$ activities in $\mathrm{Fe}_{x} \mathrm{O}-\mathrm{MgO}$ solid solutions in equilibrium with pure solid iron, investigated under a stream of $\mathrm{H}_{2}+\mathrm{H}_{2} \mathrm{O}$ at $1123 \mathrm{~K}$ by Berthet and Perrot. ${ }^{6}$ )

Electrochemical measurements involving $\mathrm{CaO}$-stabilized zirconia as a solid electrolyte and a two-phase mixture of $\mathrm{Fe}+$ pure $\mathrm{Fe}_{x} \mathrm{O}$ as a reference electrode were conducted in order to determine the $\mathrm{Fe}_{x} \mathrm{O}$ activities in magnesiowüstite in contact with solid iron at temperatures between 1073 and $1373 \mathrm{~K}$ by Abbattista et al. ${ }^{7)}$ (solid squares in Fig. 2).

By employing both an electrochemical technique (solid triangles in Fig. 2) and a gas equilibrium method (open triangles), the activities of $\mathrm{Fe}_{x} \mathrm{O}$ in $\mathrm{Fe}_{x} \mathrm{O}-\mathrm{MgO}$ solid solutions in equilibrium with metallic iron were measured in the temperature interval from 1050 to 1400 and at $1573 \mathrm{~K}$ by Srecec et al. $^{8)}$

The literature data for $\mathrm{Fe}_{x} \mathrm{O}$ activities were in good agreement with each others at temperatures between 1073

*Graduate Student, Kyoto University

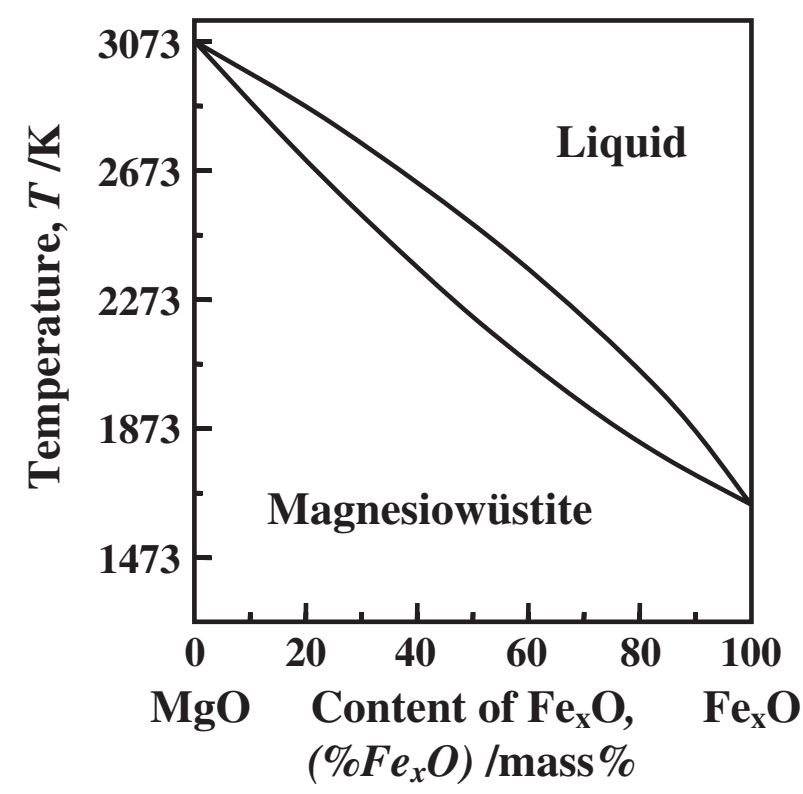

Fig. 1 Phase diagram of the system $\mathrm{MgO}-\mathrm{Fe}_{x} \mathrm{O}$ in equilibrium with metallic iron.

and $1273 \mathrm{~K}$. Agreements, however, were not satisfactory among the values of $\mathrm{Fe}_{x} \mathrm{O}$ potentials reported at 1373 and $1573 \mathrm{~K}$, respectively. Therefore, in this study, the activities of $\mathrm{Fe}_{x} \mathrm{O}$ in magnesiowüstite were measured at temperatures between 1373 and $1573 \mathrm{~K}$, in order to estimate the dependence of the $\mathrm{Fe}_{x} \mathrm{O}$ potential on temperature. $\mathrm{Fe}_{x} \mathrm{O}-\mathrm{MgO}$ solid solutions were brought into equilibrium with pure solid iron, and the equilibrium oxygen partial pressures were measured by means of a solid-oxide galvanic cell:

$$
\begin{gathered}
+) \mathrm{Mo} / \mathrm{Mo}+\mathrm{MoO}_{2} / \mathrm{ZrO}_{2}(\mathrm{MgO}) / \mathrm{Fe}(\mathrm{s}) \\
+\left\langle\mathrm{Fe}_{x} \mathrm{O}-\mathrm{MgO}\right\rangle_{\mathrm{SS}} / \mathrm{Ag} / \mathrm{Fe}(-
\end{gathered}
$$

\section{Experimental Aspects}

$\mathrm{Fe}_{x} \mathrm{O}-\mathrm{MgO}$ solid solutions were prepared by mixing iron oxide and magnesia. The mixtures were pressed in a steel die to form pellets of $20 \mathrm{~mm}$ diameter and fired in a magnesia crucible at $1573 \mathrm{~K}$ for $200 \mathrm{~h}$ under a stream of purified argon. 


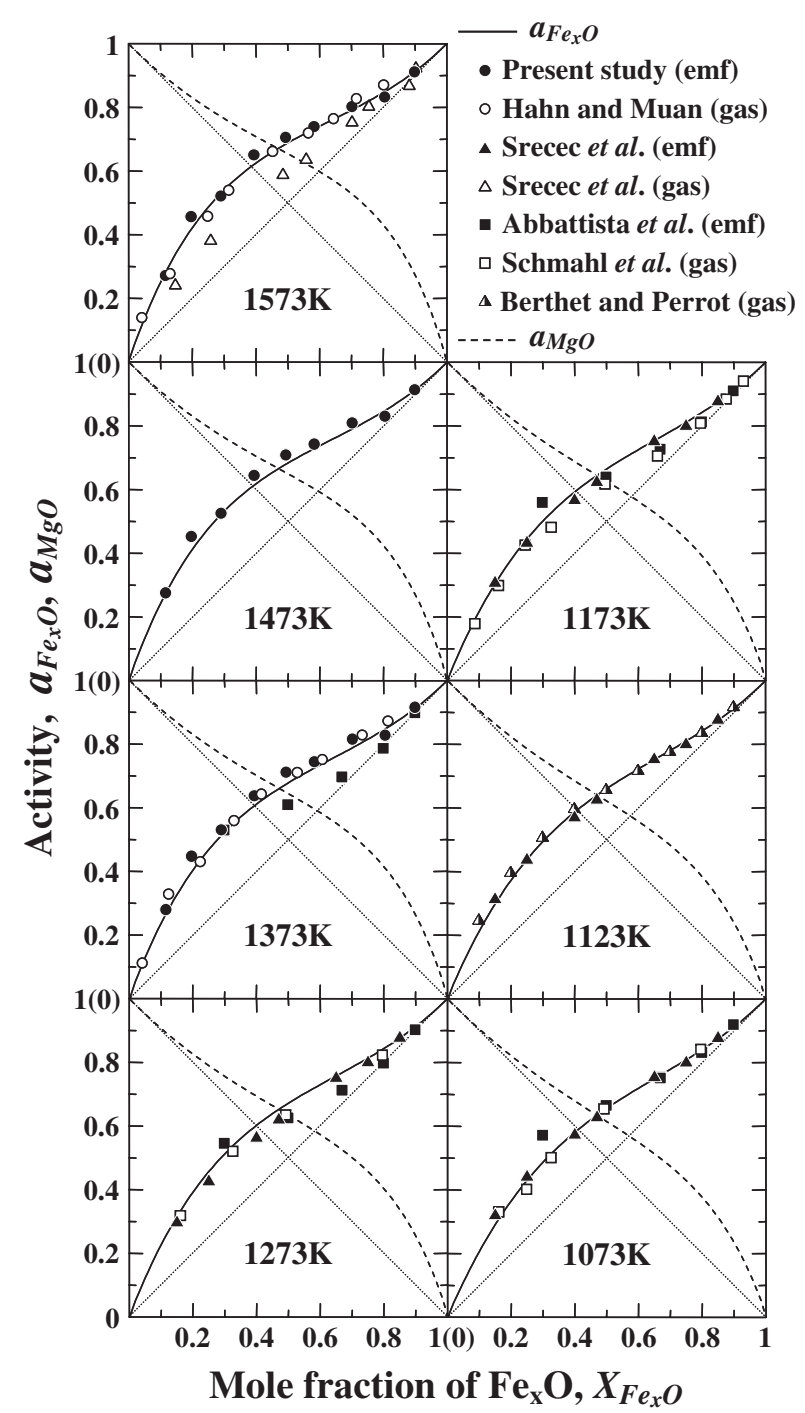

Fig. 2 Activity-composition relationship in $\mathrm{Fe}_{x} \mathrm{O}-\mathrm{MgO}$ solid solution in equilibrium with metallic iron.

The compositions of the $\mathrm{Fe}_{x} \mathrm{O}-\mathrm{MgO}$ solid solutions were determined by wet chemical analysis. The mole factions of $\mathrm{Fe}_{x} \mathrm{O}, X_{\mathrm{Fe}_{x} \mathrm{O}}$, were calculated by using a manner described elsewhere. ${ }^{9)}$

The experimental apparatus and procedures have also been described elsewhere. ${ }^{9)}$ An iron crucible was charged with 2 to $4 \mathrm{~g}$ of the $\mathrm{Fe}_{x} \mathrm{O}-\mathrm{MgO}$ solid solution and $35 \mathrm{~g}$ of pure silver, and heated to the experimental temperature under a stream of purified argon inside a $\mathrm{SiC}$ resistance furnace. The gas purification train consisted of silica-gel, phosphorus pentoxide and magnesium chips held at $823 \mathrm{~K}$.

The electrochemical oxygen probe, $\mathrm{Mo} / \mathrm{Mo}+\mathrm{MoO}_{2} /$ $\mathrm{ZrO}_{2}(\mathrm{MgO})$, consisted of a zirconia tube and a two-phase mixture of $\mathrm{Mo}+\mathrm{MoO}_{2}$. A molybdenum rod of $3 \mathrm{~mm}$ diameter was used as an electrical lead to the reference electrode, which consisted of four parts Mo and one part $\mathrm{MoO}_{2}$ by weight. The electrical contact to the outer electrode of the zirconia probe was made by the liquid silver and a steel rod soldered to the iron crucible. The use of dissimilar electrical connectors required a correction for the thermoelectromotive force of the steel-molybdenum couple. ${ }^{10)}$ The

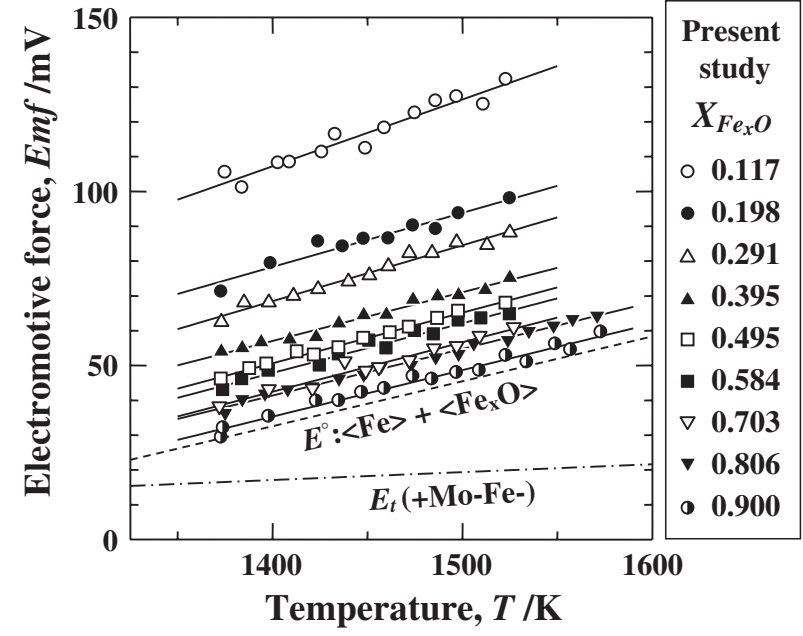

Fig. 3 Measured electromotive force as function of temperature.

zirconia tube used in this study had satisfactory resistance to even $\mathrm{Fe}_{x} \mathrm{O}$-containing liquid slags, as already reported elsewhere. ${ }^{9)}$ In this study, the oxide phase occurred at solid state, hence, reaction was negligible.

The open-circuit emfs of the oxygen probes were monitored on a strip-chart recorder of $2 \mathrm{M} \Omega$ internal impedance with an accuracy of $\pm 0.1 \mathrm{mV}$. The emf values could also be read with a digital voltmeter of $100 \mathrm{M} \Omega$ input resistance with an accuracy of $\pm 0.01 \mathrm{mV}$. Emf readings were continued until the values became stable, and the reproducibilities of cell potentials were confirmed by temperature cycling.

Temperatures were measured with a Pt-PtRh13 thermocouple and controlled to $\pm 1 \mathrm{~K}$ by using a control thermocouple and PID-type temperature regulator.

\section{Experimental Results}

The experimental results are summarized in Table 1, and Fig. 3 shows the measured values of emfs as functions of temperature.

The oxygen partial pressures of the $\mathrm{Fe}_{x} \mathrm{O}-\mathrm{MgO}$ solid solution in equilibrium with solid iron, $P_{\mathrm{O}_{2}}$, can be calculated by ${ }^{11)}$

$$
\begin{aligned}
E= & (R T / F) \ln \left[\left\{P_{\mathrm{O}_{2}}(\text { ref. })^{1 / 4}\right.\right. \\
& \left.\left.+P_{e}{ }^{1 / 4}\right\} /\left\{P_{\mathrm{O}_{2}}{ }^{1 / 4}+P_{e}{ }^{1 / 4}\right\}\right]+E_{t},
\end{aligned}
$$

where $E$ is cell voltage, $R$ is the gas constant, $T$ is temperature, $F$ is the Faraday constant, $E_{t}$ is thermo-emf between Mo (positive) and Fe (negative), and $P_{e}$ is the oxygen partial pressure at which the ionic and the $n$-type electronic conductivities are equal. Values for this parameter for the magnesia-stabilized zirconia tubes used in this study have been reported elsewhere. ${ }^{12)}$

$$
\log \left(P_{e} / \mathrm{Pa}\right)=2.54 \times 10-6.45 \times 10^{4} /(T / \mathrm{K})
$$

The oxygen partial pressure at the reference electrode, $P_{\mathrm{O}_{2}}$ (ref.), was calculated by using the authors' previous results. ${ }^{13)}$

$$
\log \left(P_{\mathrm{O}_{2}}(r e f .) / \mathrm{Pa}\right)=1.39 \times 10-3.01 \times 10^{4} /(T / \mathrm{K})
$$


Table 1 The experimental results.

\begin{tabular}{|c|c|c|c|c|c|}
\hline Sample No. & $\begin{array}{c}\text { Mole fraction } \\
\text { of } \mathrm{Fe}_{x} \mathrm{O} \text {, } \\
\quad X_{\mathrm{Fe}_{x} \mathrm{O}}\end{array}$ & $x$ & $\begin{array}{l}\text { Electromotive force, } \\
\qquad E m f / \mathrm{mV}\end{array}$ & $\begin{array}{c}\text { Temperature, } \\
T / \mathrm{K}\end{array}$ & $\begin{array}{c}\text { Oxygen partial } \\
\text { pressure, } \\
\log \left(P_{\mathrm{O}_{2}} / \mathrm{Pa}\right)\end{array}$ \\
\hline \multirow[t]{11}{*}{1} & 0.117 & 0.987 & 105.5 & 1375 & -9.35 \\
\hline & & & 111.3 & 1426 & -8.59 \\
\hline & & & 108.2 & 1403 & -8.92 \\
\hline & & & 112.4 & 1449 & -8.24 \\
\hline & & & 122.5 & 1475 & -7.98 \\
\hline & & & 132.2 & 1523 & -7.41 \\
\hline & & & 126.0 & 1486 & -7.86 \\
\hline & & & 125.0 & 1511 & -7.48 \\
\hline & & & 101.1 & 1384 & -9.13 \\
\hline & & & 116.4 & 1433 & -8.55 \\
\hline & & & 118.2 & 1459 & -8.17 \\
\hline \multirow[t]{10}{*}{2} & 0.198 & 0.992 & 71.2 & 1373 & -8.88 \\
\hline & & & 90.2 & 1474 & -7.55 \\
\hline & & & 79.4 & 1399 & -8.57 \\
\hline & & & 86.4 & 1448 & -7.89 \\
\hline & & & 85.6 & 1424 & -8.26 \\
\hline & & & 98.0 & 1525 & -6.93 \\
\hline & & & 93.7 & 1498 & -7.25 \\
\hline & & & 89.2 & 1486 & -7.36 \\
\hline & & & 86.5 & 1461 & -7.70 \\
\hline & & & 84.2 & 1437 & -8.03 \\
\hline \multirow[t]{12}{*}{3} & 0.291 & 0.994 & 62.5 & 1373 & -8.75 \\
\hline & & & 82.3 & 1472 & -7.47 \\
\hline & & & 75.9 & 1451 & -7.70 \\
\hline & & & 71.9 & 1424 & -8.06 \\
\hline & & & 88.2 & 1525 & -6.80 \\
\hline & & & 85.4 & 1497 & -7.15 \\
\hline & & & 82.3 & 1484 & -7.30 \\
\hline & & & 84.6 & 1513 & -6.92 \\
\hline & & & 70.0 & 1411 & -8.24 \\
\hline & & & 78.5 & 1461 & -7.59 \\
\hline & & & 74.1 & 1440 & -7.84 \\
\hline & & & 68.1 & 1385 & -8.64 \\
\hline \multirow[t]{13}{*}{4} & 0.395 & 0.985 & 54.0 & 1373 & -8.63 \\
\hline & & & 68.9 & 1474 & -7.26 \\
\hline & & & 56.7 & 1394 & -8.32 \\
\hline & & & 64.5 & 1448 & -7.59 \\
\hline & & & 58.2 & 1423 & -7.88 \\
\hline & & & 75.2 & 1525 & -6.62 \\
\hline & & & 70.2 & 1498 & -6.93 \\
\hline & & & 69.9 & 1487 & -7.09 \\
\hline & & & 71.7 & 1512 & -6.76 \\
\hline & & & 62.1 & 1435 & -7.75 \\
\hline & & & 64.6 & 1460 & -7.41 \\
\hline & & & 57.5 & 1409 & -8.09 \\
\hline & & & 55.0 & 1384 & -8.46 \\
\hline
\end{tabular}


Table 1 (Continued)

\begin{tabular}{|c|c|c|c|c|c|}
\hline Sample No. & $\begin{array}{l}\text { Mole fraction } \\
\text { of } \mathrm{Fe}_{x} \mathrm{O} \\
\quad X_{\mathrm{Fe}_{x} \mathrm{O}}\end{array}$ & $x$ & $\begin{array}{l}\text { Electromotive force, } \\
\qquad E m f / \mathrm{mV}\end{array}$ & $\begin{array}{c}\text { Temperature, } \\
T / \mathrm{K}\end{array}$ & $\begin{array}{c}\text { Oxygen partial } \\
\text { pressure, } \\
\log \left(P_{\mathrm{O}_{2}} / \mathrm{Pa}\right)\end{array}$ \\
\hline \multirow[t]{10}{*}{5} & 0.495 & 0.994 & 46.1 & 1373 & -8.51 \\
\hline & & & 61.0 & 1472 & -7.18 \\
\hline & & & 50.4 & 1397 & -8.18 \\
\hline & & & 57.8 & 1448 & -7.49 \\
\hline & & & 67.9 & 1523 & -6.55 \\
\hline & & & 65.6 & 1498 & -6.87 \\
\hline & & & 63.5 & 1487 & -7.00 \\
\hline & & & 55.1 & 1435 & -7.65 \\
\hline & & & 59.4 & 1462 & -7.31 \\
\hline & & & 53.9 & 1413 & -7.98 \\
\hline \multirow[t]{12}{*}{6} & 0.584 & 0.995 & 42.9 & 1374 & -8.45 \\
\hline & & & 59.9 & 1475 & -7.12 \\
\hline & & & 48.5 & 1398 & -8.14 \\
\hline & & & 57.1 & 1451 & -7.44 \\
\hline & & & 50.0 & 1425 & -7.74 \\
\hline & & & 64.7 & 1525 & -6.49 \\
\hline & & & 62.9 & 1498 & -6.84 \\
\hline & & & 63.5 & 1510 & -6.68 \\
\hline & & & 54.9 & 1460 & -7.27 \\
\hline & & & 58.9 & 1485 & -6.97 \\
\hline & & & 53.2 & 1435 & -7.63 \\
\hline & & & 46.1 & 1384 & -8.33 \\
\hline \multirow[t]{10}{*}{7} & 0.703 & 0.999 & 38.3 & 1372 & -8.41 \\
\hline & & & 43.4 & 1421 & -7.70 \\
\hline & & & 48.5 & 1449 & -7.35 \\
\hline & & & 43.2 & 1398 & -8.06 \\
\hline & & & 61.0 & 1527 & -6.41 \\
\hline & & & 55.6 & 1497 & -6.75 \\
\hline & & & 58.5 & 1509 & -6.62 \\
\hline & & & 54.9 & 1485 & -6.91 \\
\hline & & & 51.2 & 1438 & -7.55 \\
\hline & & & 49.5 & 1456 & -7.26 \\
\hline \multirow[t]{17}{*}{8} & 0.806 & 0.993 & 64.3 & 1571 & -5.87 \\
\hline & & & 57.3 & 1524 & -6.40 \\
\hline & & & 61.4 & 1548 & -6.13 \\
\hline & & & 50.1 & 1473 & -7.02 \\
\hline & & & 53.3 & 1498 & -6.71 \\
\hline & & & 47.3 & 1448 & -7.35 \\
\hline & & & 41.9 & 1396 & -8.08 \\
\hline & & & 44.0 & 1421 & -7.71 \\
\hline & & & 36.3 & 1375 & -8.34 \\
\hline & & & 63.3 & 1558 & -6.03 \\
\hline & & & 56.3 & 1506 & -6.63 \\
\hline & & & 59.9 & 1535 & -6.29 \\
\hline & & & 49.6 & 1457 & -7.25 \\
\hline & & & 40.3 & 1384 & -8.25 \\
\hline & & & 46.2 & 1435 & -7.53 \\
\hline & & & 43.1 & 1408 & -7.90 \\
\hline & & & 52.3 & 1486 & -6.86 \\
\hline
\end{tabular}


Table 1 (Continued)

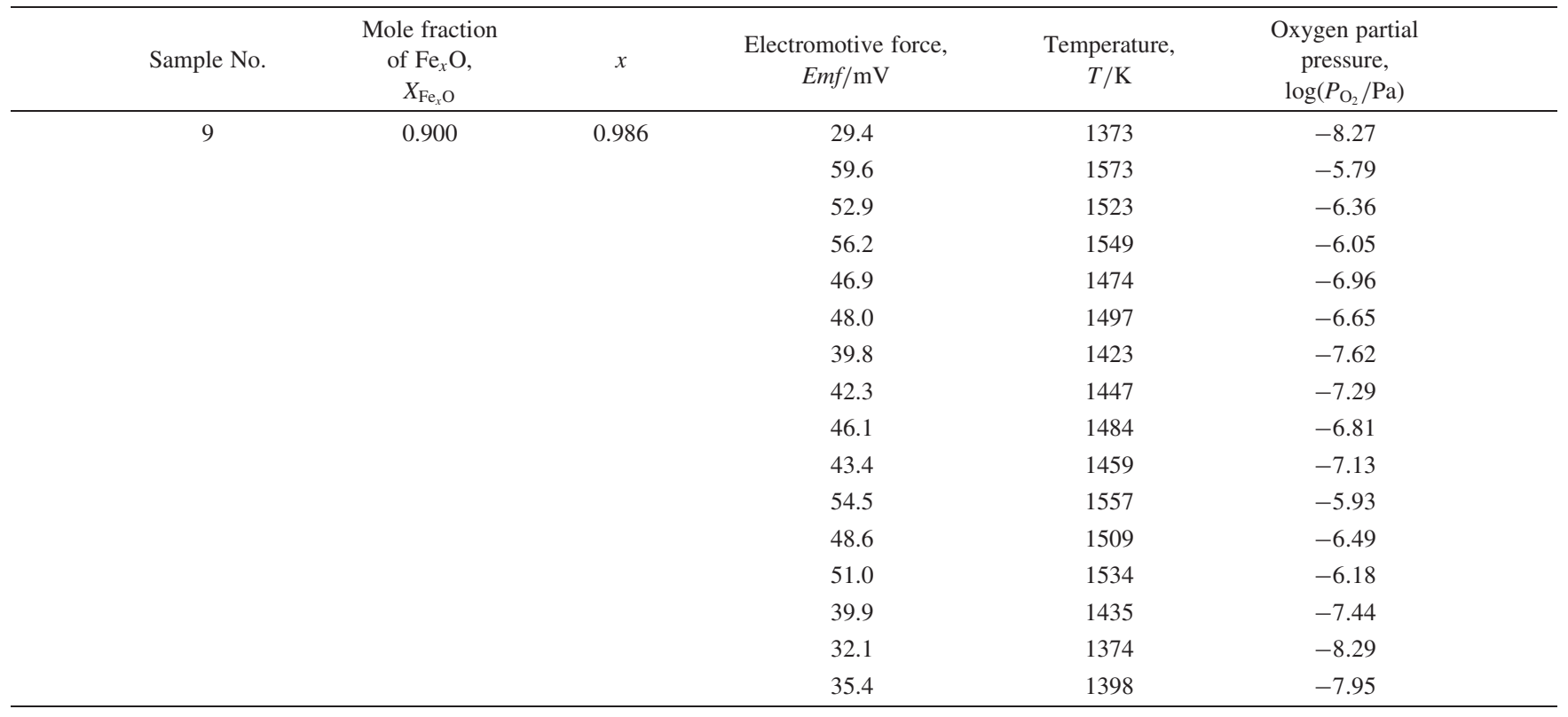

The standard state for $\mathrm{Fe}_{x} \mathrm{O}$ was taken as pure nonstoichiometric solid $\mathrm{Fe}_{x} \mathrm{O}$ in equilibrium with pure solid iron. The activities of $\mathrm{Fe}_{x} \mathrm{O}$ were calculated by

$$
a_{\mathrm{Fe}_{x} \mathrm{O}}=\left(P_{\mathrm{O}_{2}} / P_{\mathrm{O}_{2}}{ }^{\circ}\left\langle\mathrm{Fe}_{x} \mathrm{O}\right\rangle\right)^{1 / 2},
$$

where $P_{\mathrm{O}_{2}}{ }^{\circ}\left\langle\mathrm{Fe}_{x} \mathrm{O}\right\rangle$ is the equilibrium oxygen partial pressure of the mixture of pure solid iron and pure solid $\mathrm{Fe}_{x} \mathrm{O}$, as given by the formula ${ }^{10)}$

$$
\log \left(P_{\mathrm{O}_{2}}{ }^{\circ}\left\langle\mathrm{Fe}_{x} \mathrm{O}\right\rangle / \mathrm{Pa}\right)=1.17 \times 10-2.74 \times 10^{4} /(T / \mathrm{K})
$$

\section{Discussion}

The mole ratios of $\mathrm{Fe}^{3+} / \mathrm{Fe}^{2+}$ in $\mathrm{Fe}_{x} \mathrm{O}-\mathrm{MgO}$ solid solutions in equilibrium with solid metallic iron and values of $x$ in Table 1 were considered to change slightly, depending upon temperature. In this study, however, the compositions of $\mathrm{Fe}_{x} \mathrm{O}-\mathrm{MgO}$ solid solutions were determined only after preparations at $1573 \mathrm{~K}$, and are superimposed on the isothermal section of the ternary system of stoichiometric $\mathrm{FeO}$, $\mathrm{Fe}_{2} \mathrm{O}_{3}$ and $\mathrm{MgO}$ at $1573 \mathrm{~K},{ }^{14)}$ shown in Fig. 4.

The present values of $\mathrm{Fe}_{x} \mathrm{O}$ activities are plotted against $\mathrm{Fe}_{x} \mathrm{O}$ mole fractions in Fig. 2, in comparison with the literature data. The $\mathrm{Fe}_{x} \mathrm{O}$ activities determined in this study show positive deviations from Raoult's law, and are in good agreement with those reported by Hahn and Muan with a gas equilibrium method at 1373 and $1573 \mathrm{~K}$.

In order to estimate the dependence of the $\mathrm{Fe}_{x} \mathrm{O}$ potential on temperature, the sub-regular solution model was applied to the activity coefficient of $\mathrm{Fe}_{x} \mathrm{O}$ in $\mathrm{Fe}_{x} \mathrm{O}-\mathrm{MgO}$ solid solutions in equilibrium with solid metallic iron:

$$
\begin{aligned}
\ln \gamma_{\mathrm{Fe}_{x} \mathrm{O}} & \equiv \ln \left(a_{\mathrm{Fe}_{x} \mathrm{O}} / X_{\mathrm{Fe}_{x} \mathrm{O}}\right) \\
& =\alpha\left(1-X_{\mathrm{Fe}_{x} \mathrm{O}}\right)^{3}+\beta\left(1-X_{\mathrm{Fe}_{x} \mathrm{O}}\right)^{2}
\end{aligned}
$$

where parameters $\alpha$ and $\beta$ depend on temperature only. By using the least squared method to all the data for $\mathrm{Fe}_{x} \mathrm{O}$ activities determined in this study and the literatures, parameters $\alpha$ and $\beta$ could be derived as follows:

$$
\begin{gathered}
\alpha=-1.72 \times 10^{-1}-3.34 \times 10^{2} /(T / \mathrm{K}) \\
(1073-1573 \mathrm{~K}) \\
\beta=1.78-4.84 \times 10^{2} /(T / \mathrm{K}) \\
(1073-1573 \mathrm{~K})
\end{gathered}
$$

Thus, we have

$$
\begin{aligned}
\ln \gamma_{\mathrm{Fe}_{x} \mathrm{O}}= & \left\{-1.72 \times 10^{-1}-3.34\right. \\
& \left.\times 10^{2} /(T / \mathrm{K})\right\}\left(1-X_{\mathrm{Fe}_{x} \mathrm{O}}\right)^{3} \\
& +\left\{1.78-4.84 \times 10^{2} /(T / \mathrm{K})\right\}\left(1-X_{\mathrm{Fe}_{x} \mathrm{O}}\right)^{2}
\end{aligned}
$$

The $\mathrm{Fe}_{x} \mathrm{O}$ activity-composition relationships at 1573, $1473,1373,1273,1173,1123$ and $1073 \mathrm{~K}$ were calculated by using eq. (10), and are expressed by the solid curves in Fig. 2. At 1373 and $1573 \mathrm{~K}$, the $\mathrm{Fe}_{x} \mathrm{O}$ activity values reported by the present authors and Hahn and Muan are in good agreement with those derived from eq. (10), while values of Srecec et al. (gas) and Abbattista et al. (emf) show negative deviation from the calculated ones. The smooth curves calculated by eq. (10), however, could represent the $\mathrm{Fe}_{x} \mathrm{O}$ activities at temperatures between 1073 and $1573 \mathrm{~K}$ with an accuracy of \pm 0.02 , which was attributed to the average difference of the calculated values from the experimental data. The deviation of $\mathrm{Fe}_{x} \mathrm{O}$ activities from Raoult's law increases slightly with an increase in temperature in this temperature range.

By applying the sub-regular solution model to $\mathrm{Fe}_{x} \mathrm{O}-\mathrm{MgO}$ solid solution, the activity coefficient of $\mathrm{MgO}$ was also given as:

$$
\begin{aligned}
\ln \gamma_{\mathrm{MgO}} \equiv & \ln \left(a_{\mathrm{MgO}} /\left(1-X_{\mathrm{Fe}_{x} \mathrm{O}}\right)\right) \\
= & -\alpha X_{\mathrm{Fe}_{x} \mathrm{O}}{ }^{3}+\{(3 \alpha+2 \beta) / 2\} X_{\mathrm{Fe}_{x} \mathrm{O}}{ }^{2} \\
= & \left\{1.72 \times 10^{-1}+3.34 \times 10^{2} /(T / \mathrm{K})\right\} X_{\mathrm{Fe}_{x} \mathrm{O}}{ }^{3} \\
& +\left\{1.52-9.85 \times 10^{2} /(T / \mathrm{K})\right\} X_{\mathrm{Fe}_{x} \mathrm{O}}{ }^{2}
\end{aligned}
$$




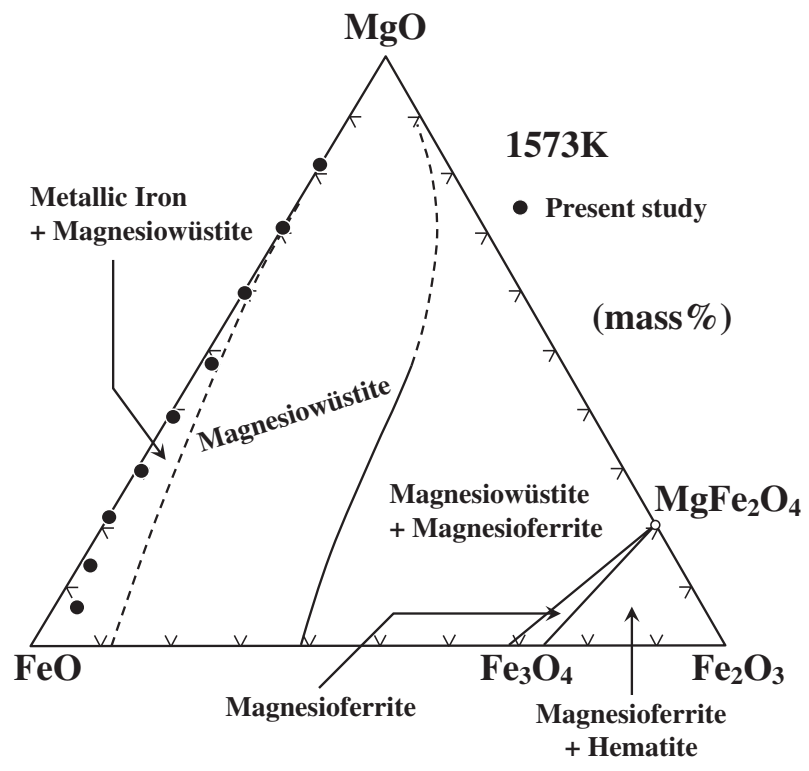

Fig. 4 Iso-thermal section of the system $\mathrm{FeO}-\mathrm{Fe}_{2} \mathrm{O}_{3}-\mathrm{MgO}$ at $1573 \mathrm{~K}$.

Equations (7) and (11) satisfy the Gibbs-Duhem equation (13) at constant temperature.

$$
X_{\mathrm{Fe}_{x} \mathrm{O}} \mathrm{d}\left(\ln \gamma_{\mathrm{Fe}_{x} \mathrm{O}}\right)+\left(1-X_{\mathrm{Fe}_{x} \mathrm{O}}\right) \mathrm{d}\left(\ln \gamma_{\mathrm{MgO}}\right)=0
$$

The $\mathrm{MgO}$ activities were calculated by eq. (12), and are represented by the broken curves in Fig. 2 .

The relative partial molar Gibbs free energy of $\mathrm{Fe}_{x} \mathrm{O}$, $\Delta \bar{G}_{\mathrm{Fe}_{x} \mathrm{O}}$, referred to pure nonstoichiometric solid $\mathrm{Fe}_{x} \mathrm{O}$ in equilibrium with pure solid metallic iron was calculated from eq. (10).

$$
\begin{aligned}
& \Delta \bar{G}_{\mathrm{Fe}_{x} \mathrm{O}} \equiv R T \ln \gamma_{\mathrm{Fe}_{x} \mathrm{O}}+R T \ln X_{\mathrm{Fe}_{x} \mathrm{O}} \\
& \Delta \bar{G}_{\mathrm{Fe}_{x} \mathrm{O}} / \mathrm{J} \cdot \mathrm{mol}^{-1}=\left\{-1.43(T / \mathrm{K})-2.78 \times 10^{3}\right\} \\
& \times\left(1-X_{\mathrm{Fe}_{x} \mathrm{O}}\right)^{3}+\{1.48 \times 10(T / \mathrm{K}) \\
& \left.-4.02 \times 10^{3}\right\}\left(1-X_{\mathrm{Fe}_{x} \mathrm{O}}\right)^{2} \\
& +R T \ln X_{\mathrm{Fe}_{x} \mathrm{O}}
\end{aligned}
$$

The relative partial molar enthalpy, $\Delta \bar{H}_{\mathrm{Fe}_{x} \mathrm{O}}$, and entropy, $\Delta \bar{S}_{\mathrm{Fe}_{\mathrm{x}} \mathrm{O}}$, could be given by using eq. (15) and the GibbsHelmholtz equations. (16) and (18), respectively.

$$
\begin{aligned}
\Delta \bar{H}_{\mathrm{Fe}_{x} \mathrm{O}} \equiv & -T^{2}\left[\partial\left(\Delta \bar{G}_{\mathrm{Fe}_{x} \mathrm{O}} / T\right) / \partial T\right]_{P} \\
\Delta \bar{H}_{\mathrm{Fe}_{x} \mathrm{O}} / \mathrm{J} \cdot \mathrm{mol}^{-1}= & -2.78 \times 10^{3}\left(1-X_{\mathrm{Fe}_{x} \mathrm{O}}\right)^{3} \\
& -4.02 \times 10^{3}\left(1-X_{\mathrm{Fe}_{x} \mathrm{O}}\right)^{2} \\
\Delta \bar{S}_{\mathrm{Fe}_{x} \mathrm{O}} \equiv & -\left[\partial \Delta \bar{G}_{\mathrm{Fe}_{x} \mathrm{O}} / \partial T\right]_{P} \\
\Delta \bar{S}_{\mathrm{Fe}_{x} \mathrm{O}} / \mathrm{J} \cdot \mathrm{mol}^{-1} \cdot \mathrm{K}^{-1}= & 1.43\left(1-X_{\mathrm{Fe}_{x} \mathrm{O}}\right)^{3}-1.48 \\
& \times 10\left(1-X_{\mathrm{Fe}_{x} \mathrm{O}}\right)^{2}-R \ln X_{\mathrm{Fe}_{x} \mathrm{O}}
\end{aligned}
$$

The relative partial molar quantities for $\mathrm{MgO}$ referred to pure solid $\mathrm{MgO}$ were also calculated from eq. (12).

$$
\begin{aligned}
\Delta \bar{G}_{\mathrm{MgO}} / \mathrm{J} \cdot \mathrm{mol}^{-1}= & \left\{1.43(T / \mathrm{K})+2.78 \times 10^{3}\right\} X_{\mathrm{Fe}_{x} \mathrm{O}}{ }^{3} \\
& +\{1.26 \times 10(T / \mathrm{K})-8.19 \\
& \left.\times 10^{3}\right\} X_{\mathrm{Fe}_{x} \mathrm{O}}{ }^{2}+R T \ln \left(1-X_{\mathrm{Fe}_{x} \mathrm{O}}\right)
\end{aligned}
$$

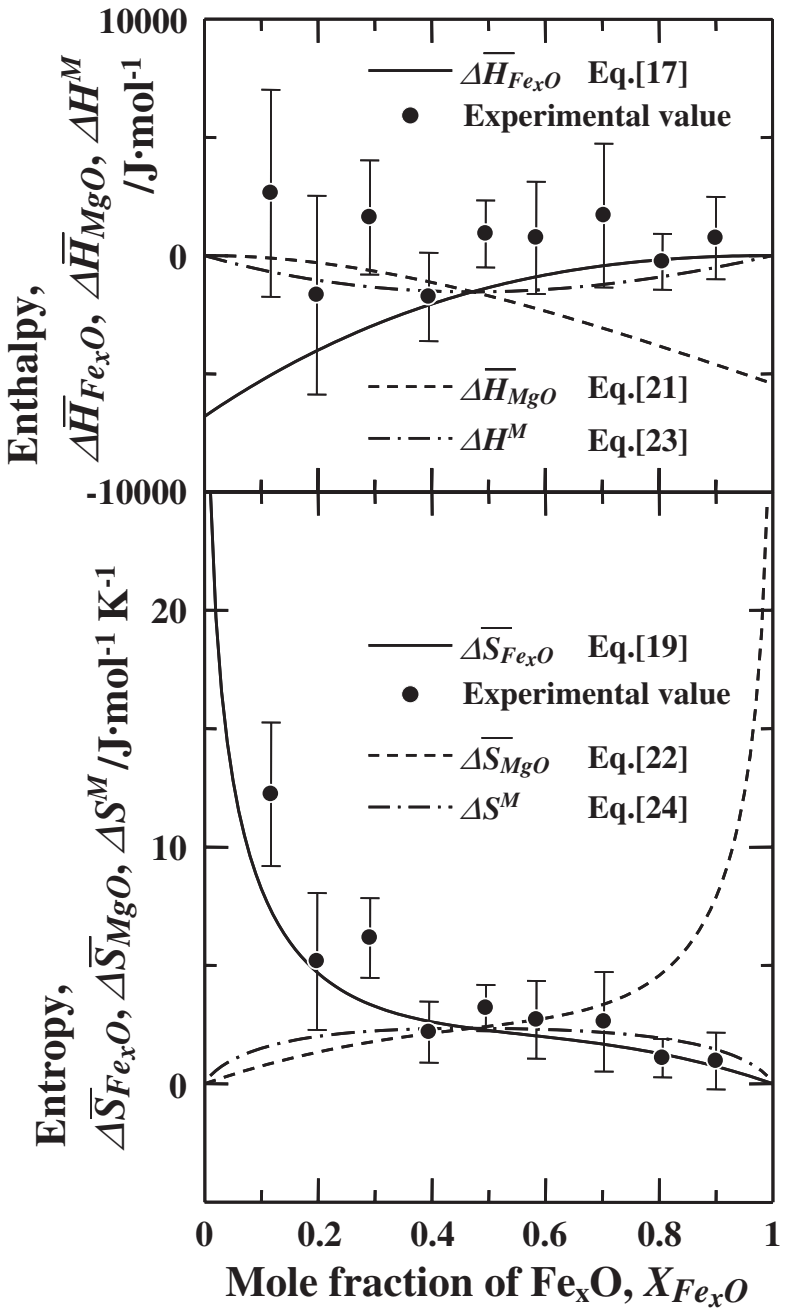

Fig. 5 Enthalpy and entropy of mixing, and relative partial molar quantities in $\mathrm{Fe}_{x} \mathrm{O}-\mathrm{MgO}$ solid solution in equilibrium with metallic iron.

$$
\begin{aligned}
\Delta \bar{H}_{\mathrm{MgO}} / \mathrm{J} \cdot \mathrm{mol}^{-1}= & 2.78 \times 10^{3} X_{\mathrm{Fe}_{x} \mathrm{O}}{ }^{3}-8.19 \\
& \times 10^{3} X_{\mathrm{Fe}_{x} \mathrm{O}}{ }^{2} \\
\Delta \bar{S}_{\mathrm{MgO}} / \mathrm{J} \cdot \mathrm{mol}^{-1} \cdot \mathrm{K}^{-1}= & -1.43 X_{\mathrm{Fe}_{x} \mathrm{O}}{ }^{3}-1.26 \\
& \times 10 X_{\mathrm{Fe}_{x} \mathrm{O}}{ }^{2}-R \ln \left(1-X_{\mathrm{Fe}_{x} \mathrm{O}}\right)
\end{aligned}
$$

Then, the enthalpy and entropy of mixing, $\Delta H^{M}, \Delta S^{M}$ could be given as follows, respectively.

$$
\begin{aligned}
& \Delta H^{M}=X_{\mathrm{Fe}_{x} \mathrm{O}} \Delta \bar{H}_{\mathrm{Fe}_{x} \mathrm{O}}+\left(1-X_{\mathrm{Fe}_{x} \mathrm{O}}\right) \Delta \bar{H}_{\mathrm{MgO}} \\
& \Delta S^{M}=X_{\mathrm{Fe}_{x} \mathrm{O}} \Delta \bar{S}_{\mathrm{Fe}_{x} \mathrm{O}}+\left(1-X_{\mathrm{Fe}_{x} \mathrm{O}}\right) \Delta \bar{S}_{\mathrm{MgO}}
\end{aligned}
$$

The relative partial molar quantities for $\mathrm{Fe}_{x} \mathrm{O}$ and $\mathrm{MgO}$ and the enthalpy and entropy of mixing are summarized in Fig. 5. In this model, the relative partial molar enthalpy and entropy are independent of temperature.

On the other hand, the relative partial molar enthalpy and entropy of $\mathrm{Fe}_{x} \mathrm{O}$ can be determined by using the GibbsHelmholtz equations. (16) and (18) and the linear relationships between the electromotive forces and temperature, shown in Fig. 3. 


$$
\begin{aligned}
\Delta \bar{G}_{\mathrm{Fe}_{x} \mathrm{O}} & \equiv-2 F\left(E-E^{\circ}\right) \\
& =\Delta \bar{H}_{\mathrm{Fe}_{x} \mathrm{O}}-T \Delta \bar{S}_{\mathrm{Fe}_{x} \mathrm{O}},
\end{aligned}
$$

where $E$ and $E^{\circ}$ denote the voltages of the galvanic cells:

$$
\begin{gathered}
E:+) \mathrm{Mo} / \mathrm{Mo}+\mathrm{MoO}_{2} / \mathrm{ZrO}_{2}(\mathrm{MgO}) / \mathrm{Fe}(\mathrm{s}) \\
+\left\langle\mathrm{Fe}_{x} \mathrm{O}-\mathrm{MgO}_{\mathrm{SS}} / \mathrm{Ag} / \mathrm{Fe}(-\right. \\
\left.E^{\circ}:+\right) \mathrm{Mo} / \mathrm{Mo}+\mathrm{MoO}_{2} / \mathrm{ZrO}_{2}(\mathrm{MgO}) / \mathrm{Fe}(\mathrm{s}) \\
+ \text { pure solid } \mathrm{Fe}_{x} \mathrm{O} / \mathrm{Ag} / \mathrm{Fe}(-
\end{gathered}
$$

$\Delta \bar{H}_{\mathrm{Fe}_{x} \mathrm{O}}$ and $\Delta \bar{S}_{\mathrm{Fe}_{x} \mathrm{O}}$ determined from the experimental data in this study are plotted in Fig. 5. As shown in this figure, the scatters, which are illustrated by the error bars, are large, because $\Delta \bar{H}_{\mathrm{Fe}_{x} \mathrm{O}}$ and $\Delta \bar{S}_{\mathrm{Fe}_{x} \mathrm{O}}$ correspond to the intercept and the slope of eq. (25) extrapolated at $0 \mathrm{~K}$, respectively.

For $\mathrm{Fe}_{x} \mathrm{O}-\mathrm{MgO}$ solid solutions, the $\mathrm{Fe}_{x} \mathrm{O}$ activities have been reported by Tamura et al. between 1823 and $1923 \mathrm{~K}^{15)}$ These authors reported nearly ideal behavior. In general, with an increase in temperature, activities would approach ideal solutions. Hence, the difference is not surprising.

\section{Conclusions}

(1) By employing an electrochemical technique, the activities of iron oxide, $\mathrm{Fe}_{x} \mathrm{O}$, were measured in magnesiowüstite, $\mathrm{Fe}_{x} \mathrm{O}-\mathrm{MgO}$ solid solution, in equilibrium with solid metallic iron at temperatures between 1373 and $1573 \mathrm{~K}$

(2) The $\mathrm{Fe}_{x} \mathrm{O}$ activities in $\mathrm{Fe}_{x} \mathrm{O}-\mathrm{MgO}$ solid solutions showed positive deviations from Raoult's law.

(3) Equation (10) could represent the $\mathrm{Fe}_{x} \mathrm{O}$ activity-composition relationship in the temperature range 1073 to $1573 \mathrm{~K}$ with an accuracy of \pm 0.02 .

\section{Acknowledgements}

Helpful comments, suggestions, discussion and encouragements were given by Professor Alex McLean, Ferrous Metallurgy Research Group, Department of Metallurgy and Material Science, University of Toronto, and these are gratefully acknowledged.

\section{REFERENCES}

1) N. L. Bowen and J. F. Schairer: Am. J. Sci. 29 (1935) 157-217.

2) H. Schenck and W. Pfaff: Archiv für das Eisenhüttenwesen 32 (1961) 741-751.

3) R. E. Johnson and A. Muan: J. Am. Ceram. Soc. 48 (1965) 359-364.

4) N. Schmahl, B. Frisch and G. Stock: Archiv für das Eisenhüttenwesen 32 (1961) 297-302.

5) W. C. Hahn, Jr. and A. Muan: Trans. Metall. AIME 224 (1962) 416420.

6) A. Berthet and P. Perrot: Mem. Etud. Sci. Rev. de Metall. 67 (1970) $747-753$.

7) F. Abbattista, G. B. Grassi and M. Maja: Metall. Italiana 65 (1973) 485-488.

8) I. Srecec, A. Ender, E. Woermann, W. Gans, E. Jacobsson, G. Eriksson and E. Rosen: Phys. Chem. Minerals 14 (1987) 492-498.

9) M. Iwase, N. Yamada, K. Nishida and E. Ichise: Trans. Iron Steel. Soc. AIME 4 (1984) 69-75.

10) M. Iwase, N. Yamada, E. Ichise and H. Akizuki: Trans. Iron. Steel Soc. AIME 5 (1984) 53-59.

11) H. Schmalzried: Z. Electrochem. 66 (1962) 572-576.

12) M. Iwase, E. Ichise, T. Yamasaki and M. Takeuchi: Trans. JIM 25 (1984) 43-52.

13) M. Iwase, M. Yasuda and T. Mori: Electrochimi. Acta 19 (1979) 261266.

14) D. H. Speidel: J. Am. Ceram. Soc. 50 (1967) 243-248.

15) T. Tamura, T. Nagasaka and M. Hino: ISIJ Int. 44 (2004) 476-481. 